\title{
Measuring the Indonesian SMEs' Capabilities for Sociodynamic and Disruptive Innovation: The Case for Gaining Resilience and Sustainability
}

\section{Jenri MP Panjaitan}

Bina Nusantara Universitas - Kampus Anggrek: Binus University - Anggrek Campus

\section{Muhadjir Darwin}

Gadjah Mada University: Universitas Gadjah Mada

sumiyana sumiyana ( $\nabla$ sumiyana@ugm.ac.id)

Universitas Gadjah Mada https://orcid.org/0000-0002-1518-9681

Wivaqussaniyyah Wiva

Gadjah Mada University: Universitas Gadjah Mada

\section{Servatia M Setyowati}

Duta Wacana Christian University: Universitas Kristen Duta Wacana

\section{Research}

Keywords: sociodynamics, disruptive innovation, capability, resilience, sustainability, growth

Posted Date: December 22nd, 2021

DOI: https://doi.org/10.21203/rs.3.rs-1169918/v1

License: (9) This work is licensed under a Creative Commons Attribution 4.0 International License. Read Full License 


\section{Abstract}

This study investigates: (1) How do the Indonesian SMEs posit sociodynamic factors and disruptive innovation to gain resilience and sustainability? (2) How do they behave when employing sociodynamic factors and disruptive innovation? (3) Why do they formulate strategic policies for the sociodynamic factors and then innovate disruptively? This research infers that those SMEs posit sociodynamic factors to increase their businesses' capacity by expanding their social networks and building synergy and business alliances with others. These SMEs intensively catch information about future probable economic benefits to their internal businesses. Moreover, they encourage themselves to carry out disruptive innovations that create distinctive products and new market segments. The authors designed this research method with a qualitative approach. There are three methods of data collection: in-depth interviews, observations, and document studies. Furthermore, this research selects informants from Indonesian SMEs using purposive criteria, such as their total assets or having a net income above USD 1 million (IDR 14 billion), with no restrictions on their field of business. Thus, this study firstly raises reasons why Indonesian SMEs have overcome economic downturns using sociodynamic factors and disruptive innovation. Second, the researcher shows that the Indonesian Ministry of SMEs issued policies with a fallacy, focusing on the digital economy only. Otherwise, this ministry should encourage SMEs to have a bundled knowledge of sociodynamics and disruptive innovation. Third, this study contradicts the evidence from the barriers to the Indonesian SMEs' capability enhancements in digital transformation. Otherwise, this study evidenced that most Indonesian SMEs adopt low-single-platform information.

\section{Introduction}

This study proposes that SMEs should be sociodynamics and face the realities of life and social challenges in the business world, including the COVID-19 pandemic (Pantano, Pizzi, Scarpi, \& Dennis, 2020). Moreover, this study argues that Indonesian SMEs need to conduct their business with disruptive innovation to reach global trends (Sandström, Berglund, \& Magnusson, 2014). Meanwhile, SMEs should develop themselves with sociodynamic factors to improve their business capabilities through the expansion of their social networks (Walley, 2013), business alliances (Robson \& Bennett, 2000; Swoboda, Meierer, Foscht, \& Morschett, 2011) and synergy with others (Svensrud \& Åsvoll, 2012). Therefore, this study investigates and analyses: (1) How do Indonesian SMEs develop their sociodynamic factors and disruptive innovation? (2) How do Indonesian SMEs' behaviour formulate their strategic policies for achieving business resilience and sustainability? (3) Why do they make strategic policies that are sociodynamic and then innovate disruptively?

With the rapid technological advances marked by the Industrial Revolution 4.0 (cyber-physical systems), SMEs in Indonesia are also very aggressively digitising their business operations (Bouwman, Nikou, \& de Reuver, 2019; Taiminen \& Karjaluoto, 2015). As of October 2021, 15.9 million SMEs were using digital platforms in their businesses, which is $24 \%$ of the 65 million SMEs. In addition, the Government of Indonesia (here-after Gol) encourages SMEs to immediately enter the digital economy to relieve the pressures caused by the pandemic (Priyono, Moin, \& Putri, 2020). Therefore, researchers believe that the 
main driver of economic recovery in the disruptive disruption era is the digital economy, a relevant strategy for SMEs (Kala'lembang, 2021). However, we argue that the government's loan facilitation would become useless when SMEs do not adopt sociodynamics and disruptive innovation. Furthermore, this study shows the argument's novelty is supported by critical reasoning, as follows.

First, this study shows that Indonesian SMEs have experienced an economic downturn due to increasing foreign debt and future economic uncertainty (Sumiyana, 2020; Sumiyana, Atmini, \& Sugiri, 2019). These pressures caused SMEs to acquire low-interest debt financing and suppress their growth opportunities (Alraja, Hussein, \& Ahmed, 2021). This study considers that many SMEs could overcome economic adversity by utilising sociodynamic and disruptive innovation (Sandström et al., 2014). It reiterates that SMEs should decide policies for a series of sociodynamic and disruptive innovations. In other words, this study hints at past studies (Svensrud \& Åsvoll, 2012; Walley, 2013), which showed the venture's success. Second, this study identifies the usefulness and suitability of policies issued by the Indonesian Ministry of SMEs. This ministry's policy should cover and overshadow these SMEs' businesses to be sociodynamic and create disruptive innovation. The researcher argues that the ministry of SMEs issued a policy that contains fallacies, especially on encouraging digitalisation without urging the SMEs to develop sociodynamic and disruptive innovation. Due to these partiality flaws, guidelines issued by this SMEs ministry could not leverage most Indonesian SMEs' to grow incrementally (Manish \& Sutter, 2016). Furthermore, this study criticises the Indonesian ministry's policies that do not match the needs of most Indonesian SMEs through resource facilitation and regulations.

Third, this study proposes evidence of the bounded rationality phenomenon in upgrading the Indonesian SMEs based on research by Deloitte Access Economics (DAE), which presents the barriers to digital transformation by the Indonesian SMEs. DAE explains that $36 \%$ of Indonesian SMEs still use conventional marketing methods, and only $18 \%$ promote their products or services using social media and websites. Meanwhile, as many as $37 \%$ of SMEs can only operate a computer and the internet straightforwardly. The Danareksa Research Institute also shows that $41.67 \%$ of SMEs in DKI Jakarta already use social media and digital marketing for their operating activities (CIPS, 2021). However, we also document that only $29.18 \%$ of SMEs in Java and $16.16 \%$ outside Java have utilised digital marketing. On the other hand, this study explains that most Indonesian SMEs' sustainability is due to their use of the conceptual contents of sociodynamics (Mesquita \& Boiger, 2014) and disruptive innovation (Markides, 2006; Schmidt \& Druehl, 2008), and adopting ICT for their social networks, alliances and synergy with others.

This study contributes to the managerial emphasis and the Indonesian regulator's innovative policies for these SMEs. First, this study highlights the importance of upgrading SMEs through consciously strengthening their mastery in adopting sociodynamic factors (Karami \& Tang, 2019; Pearson et al., 2002) and disruptive innovation practices (Assink, 2006; Zhang \& Zhu, 2021). Consequently, the Indonesian SMEs could increase their business levels. Second, this study argues that sociodynamic factors and disruptive innovation practices enhance the SMEs' perspectives. The authors argue that sociodynamics and disruptive innovation encourage them to capitalise on the intangible assets used for 
forward-looking orientations (Crema \& Nosella, 2014). Third, this study concludes that the Gol's policies, especially those of the Ministry of SMEs, should produce regulations of the same hierarchical level as the Indonesian SMEs' needs. These policies should not be in fallacies that most SMEs no longer need, such as financial policies. Any new policies must adhere to the logical sequence for the SMEs' business strengthening through sociodynamic factors (Bhasin \& Venkataramany, 2010; Doh \& Kim, 2014), while supporting productive social networks, sharing experiences and knowledge. Therefore, this new policy could bundle the SMEs' national collective knowledge which could furtherly create disruptive innovation.

\section{Study's Critical Perspective}

\subsection{Sustainable SMEs Conduct Dimensioned Sociodynamic Contents}

Sociodynamics argue that other people's behaviour around the environment affects individuals (Dugundji \& Gulyás, 2012; Mesquita \& Boiger, 2014; Murphey, Falout, Fukuda, \& Fukada, 2014). Furthermore, sociodynamics focuses on feedback from a person to achieve change in a particular time (Mesquita \& Boiger, 2014; Walley, 2013). In other words, active interaction affects individual behaviour in the interfeedback process of learning from each other. In addition, sociodynamics formulates that individuals become a source of increasing aggregative knowledge for different individuals (Blagoveshchenskaya, Dashkina, Lazovskaya, Ryabukhina, \& Tarkhov, 2016; Mesquita \& Boiger, 2014). Furthermore, the study examines that SMEs should be capable of creating their sociodynamics that will increase their aggregative competencies, which will improve their overall business. This study investigates the active interaction between SMEs to increase their aggregative knowledge and explore their incremental competency. Consequently, this study argues that regulators must help SMEs acquire aggregative expertise and enhance their competencies.

The sociodynamics theory explains individual behaviour patterns that usually act rationally and depend on obtaining information (Candas, Siala, \& Hamacher, 2019; Mesquita \& Boiger, 2014). The researcher infers that the SMEs' agility in overcoming problems and their ability to increase the scale of their businesses is strongly influenced by their information acquisition and the depth of their understanding, especially of the issues that hinder their businesses' progress. On the other hand, the narrower the information and the shallower the experience, the fewer options there are for solutions to problems and business development in the future. This study notes that the currently available ICT and infrastructure support information availability that meets the SMEs' needs. Therefore, this study describes how to extract information and facilities to support SMEs' business development. In this way, SMEs get relevant information to solve their problems. On the other hand, it argues that government programs supporting SMEs' competence should be equivalently suitable for the SMEs' sociodynamic levels.

Furthermore, sociodynamics focuses on individual behaviour and examines the importance of the heterogeneity of each interacting individual (Graham, 2019; Mesquita \& Boiger, 2014). Researchers argue that the need for SMEs to build social networks is no longer an option but an obligation. Social networks 
are organic-sporadic in the informal friendships of business actors but are also structurally formed based on shared interests and an understanding, impacting the importance of an active community. In sharing knowledge and experience, SMEs make a place to correct each other's mistakes and formulate joint solutions in the future. In other words, the SME community should be a human association and be a store of solutions for business development aggregately among its members on a larger scale. So, this study examines the behaviour patterns of SMEs when building social networks and sharing knowledge and experiences for developing their businesses in an aggregative manner and on a larger scale. Thus, the success of SMEs in creating a dynamic and integrative social network supports the SME businesses sustainability.

\subsection{Sustainable SMEs Employing Disruptive Innovation}

Disruptive innovation is an engineering activity to create new market segments that differ from the existing ones (Gobble, 2016). In the context of this research, disruptive innovation is closely related to the creation of value-added and bargaining power that increases a business's competitiveness. The concept of disruptive innovation demands a continuous renewal of the knowledge that SMEs must always create innovations in a dynamic market's interests. Therefore, the disruption of innovation becomes a challenge for SMEs. Disruptive innovation maximises business renewals based on limited resources, making SMEs compete in a dynamic market despite their limited resources (Chan, Teoh, Yeow, \& Pan, 2019).

Researchers argue that SMEs should innovate disruptively to maintain their existence in an active market. The reforms created through disruptive innovations target a specific market share to create efficiency and effectiveness in their businesses development.

More profoundly, the disruptive innovation argument emphasises rapid and continuous renewal and moves in tune with the needs and interests of particular market segments (Nagy, Schuessler, \& Dubinsky, 2016; Wan, Williamson, \& Yin, 2015). Meanwhile, SMEs need such speed and innovation to achieve a competitive advantage. Both serial logic and disruptive innovation are based on the SMEs' ability and courage to analyse the dynamics of the business environment that is constantly moving fast due to intensive competition (Chen, Zhu, \& Zhang, 2017). Researchers explain that SMEs innovate disruptively by observing potential market segmentation and becoming the marketing target. In detail, SMEs create a unique attraction as their main bargaining power to compete with extensive resources businesses. Once an SME has this particular attraction, it means that the SME has mastered the comprehensiveness of the disruptive innovation.

\subsection{SMEs' Continuance to Enlarge Business Scale}

The urgency of SMEs in seeking disruptive innovation is because it serves to maintain their existence in a growing business environment. This study explains that the formation of disruptive innovation cannot be separated from the process of solid and heterogeneous social dynamics. The continuity of disruptive innovation comes from the cumulative knowledge created through a series of feedback interactions between individuals and the SMEs' business environment (Chan et al., 2019). The researcher argues that the cumulative knowledge quality formed from social dynamics is related to the SMEs' interaction quality 
and heterogeneity level. The higher the interaction quantity and quality in social dynamics, the more excellent opportunities for information analysis and higher cumulative knowledge (Blagoveshchenskaya et al., 2016; Mesquita \& Boiger, 2014). On the other hand, the heterogeneity of the SMEs' environment and interactions create new information flows that increase the SMEs' experiential values (Corsaro, Cantù, \& Tunisini, 2012; Graham, 2019).

Disruptive innovation demands continuous renewal due to market dynamics and requires the support of a robust information flow to analyse the business opportunities and new market segments (Čiutienè \& Thattakath, 2014; Pandit, Joshi, Sahay, \& Gupta, 2018). The authors argue that quality cumulative knowledge ensures the information flow to support a complete series of disruptive innovation's logic. On the other hand, a series of disruptive innovations form new interactions between SMEs and the market's business segments, which create information through feedback and experience (Guttentag, 2015). Thus, a complete series of disruptive innovations become an information source that complements the SMEs' cumulative knowledge as the basis for further disruptive innovations. In this case, the researcher argues that the vitality of SMEs cannot be separated from a series of high social dynamic processes and quality disruptive innovations.

\subsection{Research Propositions}

This study explains that SMEs must be capable of social dynamics. A series of interactions in social dynamics creates cumulative knowledge that drives disruptive innovation. This context argues that an intense urgency requires SMEs to make disruptive innovations, especially to maintain their existence in a dynamic market. Combining social dynamics and quality disruptive innovation encourage SMEs to create future business changes. Moreover, they have a concern for sustainable business. This study posits Chan et al. (2019); Graham (2019); Lehner and Simlinger (2019); Pandit et al. (2018) that when SMEs are future-oriented, they consider developing their business environment. It means that these SMEs use social dynamics and disruptive innovation to emphasise a multidisciplinary approach, including economics, politics, socio-culture, demography, government, and technology. Each of these approaches represents a visionary view that SMEs can take. Furthermore, through multidisciplinary approaches, SMEs have deeper analytical capabilities and support a broad proactive view. Thus, the researcher concludes that the combination of social dynamics and quality disruptive innovation drives SMEs' success. In other words, this study proposes the need for SMEs to adopt social dynamics and disruptive innovations in an integrative concept.

\section{Research Method}

\subsection{Research Design}

This study used a qualitative research design with purposive informant selection techniques. Purposive sampling (Gentles, Charles, Ploeg, \& McKibbon, 2015; Gujarati, Porter, \& Gunasekar, 2012) suggests that researchers select informants by considering their knowledge and understanding of the research's context. However, this study chose informants relevant to the research context, especially sociodynamics, 
disruptive innovation, and business sustainability. Moreover, we selected informants who have proactive characters in the study conveying information. This study set (1) SMEs with total assets or net income above USD 1 million (IDR 14 billion). (2) It did not limit the field of business but focused on identifying those who have run social dynamics and disruptive innovations. In addition, the researchers also interviewed regulators and creditors as parties who have policies that encourage SMEs' businesses. Moreover, they have a lot of contacts and control the progress of the SMEs' businesses. This study presents all the interviewed informants in Table 1 below. 
Table 1

Informants List

\begin{tabular}{|c|c|c|c|}
\hline Name & Jobs and Institutions & Duration & Code \\
\hline \multicolumn{4}{|l|}{ Regulators: } \\
\hline Dwi Apriany & $\begin{array}{l}\text { Directorate General, Information Systems and } \\
\text { Treasury Technology, Indonesian Ministry of Finance }\end{array}$ & $01: 57: 38$ & IF01 \\
\hline Dini Hanggandari & $\begin{array}{l}\text { Director, SME Industries of Metal, Machinery, } \\
\text { Electronics, \& Transport Equipment, Indonesian } \\
\text { Industrial Ministry }\end{array}$ & $01: 40: 53$ & IF02 \\
\hline Agus Priyanto & $\begin{array}{l}\text { Deputy, Small \& Medium Enterprises, Indonesian } \\
\text { Ministry of Cooperatives and MSMEs }\end{array}$ & $01: 13: 17$ & IF03 \\
\hline Agus Suharyono & $\begin{array}{l}\text { Deputy, Social \& Environmental Responsibility, } \\
\text { Indonesian State-Owned Enterprises Ministry }\end{array}$ & $00: 47: 15$ & IF04 \\
\hline \multicolumn{4}{|l|}{ Creditors: } \\
\hline Rofikah Rochim & Commissioner, Bank Rakyat Indonesia, Co. Ltd. & 01:04:19 & IF05 \\
\hline Andika Sunandar & $\begin{array}{l}\text { Head, Planning Division of the Revolving Fund } \\
\text { Management Agency, Indonesian MSMEs Ministry }\end{array}$ & $01: 33: 20$ & IF06 \\
\hline \multicolumn{4}{|c|}{ SMEs' Owners or CEOs: } \\
\hline Ali Agus & Owner, Agromix Lestari Group & 02:29:30 & IF07 \\
\hline Alni Rahmawati & CEO, Umat Mandiri Berkemajuan, Co, Ltd. & $01: 23: 54$ & IF08 \\
\hline $\begin{array}{l}\text { I Made Ariya } \\
\text { Sanjaya }\end{array}$ & Owner, Kazee, Co, Ltd. & $00: 57: 15$ & IF09 \\
\hline Eko Prayitno & Owner, Pesona Cipta, Co, Ltd. & 01:08:49 & IF10 \\
\hline Serra Argo Rianda & Owner, Selat Solo Vien's Restaurant & $01: 22: 37$ & IF11 \\
\hline Nila Kun Afiah & Owner, Nila Kun Accounting Consultant & $01: 46: 42$ & IF12 \\
\hline Nurdiono & $\begin{array}{l}\text { Owner, Tegar TV, RS Aziza Metro, STIKES Panca } \\
\text { Bhakti }\end{array}$ & $01: 31: 55$ & IF13 \\
\hline Enny Anjayani & Owner, Wastraloka, Co, Ltd. & $01: 29: 34$ & IF14 \\
\hline Raimy Sofyan & Owner, Kai Food Indonesia, Co, Ltd. & 00:58:49 & IF15 \\
\hline $\begin{array}{l}\text { Ida Bagus Rai } \\
\text { Dharmawijaya } \\
\text { Mantra }\end{array}$ & Owner, Bandega Restaurant & $01: 24: 04$ & IF16 \\
\hline Riris Simanjuntak & Owner, Indo Risakti, Co, Ltd. & 02:04:35 & IF17 \\
\hline $\begin{array}{l}\text { Sudarsono } \\
\text { Bambang }\end{array}$ & Owner, Bangji Restaurant & $01: 10: 54$ & IF18 \\
\hline
\end{tabular}




\begin{tabular}{|llcc|}
\hline Name & Jobs and Institutions & Duration & Code \\
\hline Faisal Amri Elfas & Owner, FNF Metalindo Utama, Co, Ltd. & $01: 00: 11$ & IF19 \\
\hline Tri Sukamto & Owner, Bimuda Karya Teknik, Co, Ltd. & $01: 46: 46$ & IF20 \\
\hline 3.2 Data Collection, Analysis, and Presentation &
\end{tabular}

This study used in-depth interviews to collect data and conducted a preliminary pilot test to find the studied problems. Likewise, this study aimed to find more in-depth matters from the respondents (Gabbioneta, Greenwood, Mazzola, \& Minoja, 2013; Kornberger, Justesen, \& Mouritsen, 2011). Furthermore, this study designed the content of the in-depth interviews with the core contexts of SMEs' constructivism in social dynamics and disruptive innovation. In detail, sociodynamics asked about the will, motivation and practice for developing social networks (Walley, 2013), dealing with the problem's complexity (Jeansson \& Bredmar, 2019; Walley, 2013) and various managerial aspects (Ates, Garengo, Cocca, \& Bititci, 2013; Jeansson \& Bredmar, 2019). On the other hand, disruptive innovation investigated the SMEs actions to shift the business processes they faced. In other words, researchers analysed the SMEs' activities to defragment their business processes to become more low-cost (Ali, Gongbing, \& Mehreen, 2018; Bouwman et al., 2019) and developed variations (Priyono et al., 2020; Taiminen \& Karjaluoto, 2015). Finally, this study complemented the content of the in-depth interviews with observations on the SMEs' achievements toward their businesses' sustainability (Darcy, Hill, McCabe, \& McGovern, 2014; Shields \& Shelleman, 2015), surviving the uncertainty pressures (Tyler et al., 2020), and improving performance. (Ali et al., 2018; Bouwman et al., 2019). In essence, this study analysed the SMEs' ability to deal with various aspects of their business environment.

This study employed open coding to categorise the in-depth interview's scripts, to produce a data axis with axial coding (Scott \& Medaugh, 2017; Walia, 2015). It established the relationship between the categories and subcategories, leading to the core phenomena of the SMEs' sociodynamic factors, disruptive innovation and sustainability. This coding focused on specifying classes based on conditions: context, number of processes, and consequences (Williams \& Moser, 2019). Furthermore, this study processed selective coding to form the core categories of the scripted data in the new loaded knowledge (Williams \& Moser, 2019).

\subsection{Credibility, Validity, Reliability, and Triangulation}

This study posits Christensen and Miguel (2018), Creswell and Creswell (2017), Gibbs (2018) for its credible data design. The design included increasing the persistence of the data's observations, comprehensive analysis of the cumulative data, the fundamental analysis of the data, and reviewing the data using appropriate references. By doing this, the researchers ensured that the data from this study would be credible. Furthermore, this study designed the reliability of the data through careful examination of the collected data, including the processes of transcription, coding, and analysis. Likewise, this study sought the data's validity by using different data sources to cross-check and member checking to reduce any data bias. 
Furthermore, the researchers conducted triangulation, a data analysis approach to synthesise the contents from various sources (Guion, Diehl, \& McDonald, 2011). This study employed triangulation to identify the appropriateness of further testing the data to strengthen the interpretation of the available evidence (Guion et al., 2011; Renz, Carrington, \& Badger, 2018). This study posits Heale and Forbes (2013) to increase the data's validity by utilising and checking the data itself (Heale \& Forbes, 2013). The researchers believed that the four triangulations were appropriate to capture the SMEs' business process phenomenon in the field.

\section{Results \& Discussions}

\subsection{Entrepreneurial Characteristics as Factors to Gradually Progress}

Indonesian SMEs maintain and develop themselves during a crisis. The SMEs build internal foundations to run their businesses, and they have the entrepreneurial character to create value-added based on a spiritual or social welfare philosophy. Most Indonesian SMEs set their firms or organisations in valueadded creation, so they are agile. Moreover, the SMEs' philosophy is to educate the public, preserve the culture, and create material value for their goods/services. In other words, SMEs can progress to success with an entrepreneurial-based business. This study collected the following statements.

"SMEs management should always focus on value-added as a behavioural denominator as an entrepreneur, not a trader. Therefore, I used philosophical values, such as sustainable, integrated, intellectual, healthy, fun, and prosperous" (IF07-2.22 \& 8, IF10-8).

"I adopt Chakra Hindhu philosophy to strengthen my beliefs that could let out uncertain boundaries and gain genuine creativity" (IF16-1.2 \& 6.3, IF14-8.1).

"As an entrepreneur, I develop all my staff, so they have high work and mental qualities. On the other side, I emphasise knowledge dissemination to all the staff" (IF10-6.1, IF11-12.3).

The authors summarise the SMEs' sociodynamics to capture the potential market and global trends (Sandström et al., 2014). We identify those entrepreneurial characteristics that can develop business enlargement and differentiation. Furthermore, this study elaborates on the SMEs' acquisition of philosophical values to enhance their beliefs, attitudes, and behaviour. First, Indonesian SMEs create a specific business to fulfil market demands with unique goods or services. Second, most Indonesian SMEs search for knowledge to make products and adjust to improve their businesses. These SMEs develop their products through research and development, technology usage and staff enhancement programs. Third, organisational behaviour for Indonesian SMEs depends on their intelligence in searching integrative information (Candas et al., 2019; Mesquita \& Boiger, 2014). In other words, these SMEs set their organisational agility by thinking dynamically, liberating their relationships, and adapting flexibility. 
The authors explain that most SMEs build their organisational agility through two approaches. The first approach is occupational staff treatment for team building (Schlosser, 2015; Schoonjans, Van Cauwenberge, \& Vander Bauwhede, 2013). The treatment includes the internalisation of philosophical values. Then, the SMEs' owners continue to treat the behaviour of their staff. The second approach is the empowerment of the firms' internal control systems (Aschauer, Moro, \& Massaro, 2015). These systems are intended to defragment the business processes. Moreover, these systems comprehend all kinds of business cycles, such as human resources, inventories, marketing, financial management, etc.

\subsection{Incremental Knowledge to Empower Business Readiness}

This study captures the Indonesian SMEs' readiness in stages, building internal capacity strengths and developing their business plans. The SMEs that acquire the accumulated knowledge gained from practice and experience find incremental information to furtherly enhance their business (Guttentag, 2015; Hartarto, Panjaitan, \& Sumiyana, 2020; Lehner \& Simlinger, 2019; Sumiyana \& Susilo, 2021). This study identifies SMEs capability to assemble small-scale improvement processes that are sustainable in the long run but have a significant impact on change. This study presents some comments from the interviews below.

"As an SME player, I collaborate with cloud systems, impacting on improving learning and improving business. Moreover, SMEs should diversify and somehow replace old products with new ones" (IF15-6.23; IF10-1.1; IF 14-1.1; IF17-1; IF20-1.1)

"The characteristics of Indonesian SMEs are usually step-by-step changes. I don't dare to leapfrog. I measure this business by its internal stages of readiness" (IF17-4.1-2, IF07-1.1, IF09-5.2, IF13-1, IF14-1.1; IF15-1.1-2, IF19-5.2).

This research identifies that SMEs continuously improved and shaped their business maturity. SMEs should be skilled in looking at a business's complexity, immediately adapting it to survive in fluctuating business conditions, and not ignoring regulations. The renewal revolution moves linearly with the needs and interests of particular market segments to achieve a competitive advantage (Nagy et al., 2016; Wan et al., 2015). SMEs identify business opportunities that provide options to take advantage of or create momentum within their internal businesses (Chen et al., 2017). Most of the SMEs' players have taken advantage of the pandemic's momentum by diversifying their products or services, diversifying their business lines, and enlarging their market areas. This study found that some of the SMEs' players created new business breakthroughs during these crisis conditions. For example, some SMEs set up specialist and sub-specialist eye hospitals. In addition, other SMEs provided a breakthrough for organic egg breeders constrained by owning livestock.

\subsection{Making Intensive Partnerships as Social Capital}

The SMEs' business progress cannot be achieved alone, even though their internal capacities and capabilities are pretty good. This study identifies that SMEs in Indonesia are always trying to build 
networks with strategic parties. These social networks could be formal or informal, but always consider the interests of the business actors in the functioning of the social networks, so they can build to increase their capacity from the mutual learning process (Dugundji \& Gulyás, 2012; Murphey et al., 2014; Walley, 2013). The research informants expressed the following.

"Most SMEs develop their social networks with social media and the marketplace. The Gol and other private businesses in information and communication technologies facilitate those information technologies. On the other side, I strategically catch many kinds of communities to increase my network's enlargement." (IF11-2.2; IF19-2.3; IF10-2.3)

"The social networks facilitate product developments and marketing, from which many SMEs learn processes to be innovative. I recognise that social media supports not only the firm itself but also the collaborative ecosystems, including knowledge, regulations, and opportunities." (IF07-6; IF02-6.2; IF17-3.1; IF20-6; IF03-2)

This study highlights that SMEs do not limit themselves to following social networks. SMEs use social media when they perceive potential in industrial, cross-industry, and other strategic environments (Graham, 2019; Svensrud \& Åsvoll, 2012). Participation in social networks enhances their sociodynamic capability and increases active interaction to gain knowledge and diverse experiences. Then, these SMEs capitalise on their sociodynamic capacity to be intangible capital for aggregately developing their businesses in the practice of social networks, these SMEs select social networks that are functional and productive (Candas et al., 2019). That is when social media has no benefits, not being interpreted as mere financial losses, but the acquisition of the intensity of the exchange of ideas to carry out business processes (Candas et al., 2019). Therefore, this study underscores the need for alternatives to solve business processes and breakthrough forward-looking information's acquisition.

This study suggests that SMEs strengthen their ties and select the effectiveness of the various social networks, considering their social influence capability (Hambrick \& Lovelace, 2018). In other words, SMEs actors undergo a process of evolution and adaptation to increase their organisational capacity and capability as entrepreneurs (Mesquita \& Boiger, 2014; Walley, 2013). In the next stage, SMEs leverage the capabilities of these social networks to strengthen their penetration into future business challenges. Furthermore, this study notes the SMEs' concern for collaboration with anyone. Therefore, they consider linking and matching their business processes to the supply chain and customers. On the other hand, the Gol facilitates SMEs with a clustering pattern to form a business ecosystem upstream to downstream and connect with global markets (Blagoveshchenskaya et al., 2016; Mesquita \& Boiger, 2014). Furthermore, the Gol facilitates collaboration with the private marketplace.

\subsection{Acquiring Social Media ICT to Gain Valuable Forward- Looking Information}

This study infers that most Indonesian SMEs, if armed with self-organisation, business readiness, and social networks, motivate themselves to innovate disruptively. However, the SMEs' disruptive innovation 
capabilities require collaboration with the social media's ICT in various aspects of life, as mentioned in the following statements.

"There is an increasing number of SMEs onboarding on e-commerce platforms before and during the pandemic. The increase is 7.9 million Indonesian SMEs in 1.5 years." (IF03-2.1)

"We utilise digital controlling system (DCS) technology for the production process. The use of DCS aims to increase customers' loyalty due to our increased capability to fulfil their orders." (IF20-6.1; IF20-8.1)

This study indicates that Indonesian SMEs utilise social media and ICT to maintain and increase their businesses. In addition, they use social media's ICT to adjust various business ends in their disruptive innovation capacity. Their disruptive innovation inducts the future probable business environment (Pandit et al., 2018). By these means, most Indonesian SMEs carried out disruptive actions that transcend their short-run needs and transform their competitive advantage. For example, these SMEs usually implement disruptive innovation in internal system improvements, the acceleration of production processes, dynamic accountability, market coverage expansion, and service quality (Bouwman et al., 2019). This study suggests that the SMEs stages for disruptive innovation with their businesses' digitalisation were the right decisions and relevant to the demands of their businesses' dynamics, considering their role as the main driver of the economy in Indonesia (Kala'lembang, 2021).

A digital platform provides various data as a basis for business analysis. Therefore, SMEs are increasingly adapting to business changes to gain added value, consumer confidence, and business levels locally, nationally, and globally (Gobble, 2016; Nagy et al., 2016). Furthermore, this study analyses that disruptive innovation must be carried out by these SMEs simultaneously from their internal control systems, business processes, products, and services, to obtain optimal results. Thus, SMEs can expand their market coverage, increase the scale of their businesses and strengthen their mission and goals. As a result, SMEs could contribute to economic prosperity and sustainability at the community and national scales.

\subsection{Business Model Inducing Future Probable Economy Benefits Internally}

Indonesian SMEs have succeeded in exceeding the obstacles to their businesses. They utilise their sociodynamic capabilities to find innovative new business models (Svensrud \& Åsvoll, 2012; Walley, 2013). This research recognises that the SMEs' sociodynamic capabilities encourage exchanging ideas to build disruptive innovation in their communities. This study picks the following statements.

"I always exchange experiential knowledge with other SMEs to understand and capture ideas or solutions that are appropriate and suitable for the SMEs' business level. ICT social media platforms capture future information to develop the business. Forums in social media platforms are to give each other opportunities as vendors." (IF09-3.1; IF08-2; IF8-6.3) 
"A forum in social media's ICT supports Indonesian SMEs to enter new market segments. Most SMEs search for comprehensive foresight information to enlarge their markets and to fulfil market demands." (IF09-6; IF03-2.2)

The authors infer that the SMEs' sociodynamic capabilities focus on searching for specific cross-sectoral information to strengthen their social networks. These SMEs recognise that social networks interact with other SMEs for the learning process that gives birth to innovations. This study highlights that SMEs seek valuable foresight information induced for their business processes. On the other hand, inter-SME networks expand the supply chain by acting as suppliers of other SMEs' raw materials, distributors, and marketing channels. All the SMEs recognise that an innovative business model is essential to spur growth. The size of these inter-SME social networks allows the SMEs' players to continue in business (Hartarto et al., 2020; Latifi, Nikou, \& Bouwman, 2021; Sumiyana \& Susilo, 2021). For example, SMEs cooperate with other parties to offer new investments for the mutual ownership of shares. This study notes the characteristics of the SMEs' social networks for the expansion or diversification of their business model innovations. In addition, the innovative business models of Indonesian SMEs usually create new market niches or produce marketable products.

\subsection{Misfit Gol's Policy and Consequence}

This study marks that the SMEs' current position is not equivalent to the Gol's offering. Moreover, the authors highlight that most Indonesian SMEs have pursued their agility and dynamic flexibility. These SMEs make adaptive business innovations within social networks, such as supply-chain and customer relationships (Schoonjans et al., 2013; Sumiyana \& Susilo, 2021). Moreover, most SMEs would probably make themselves ready for change (Hartarto et al., 2020), especially for flexibility and the commitment to change organizationally. This research presents some statements to strengthen this study's arguments.

"The Gol, through the Finance Ministry, only measure SMEs by their total assets. Then, all the Gol's policies relating to the fund for leveraging the SMEs' businesses. However, the Gol identify the most suitable approach for these SMEs." (IF01-11-11.1; IF02-13; IF03-5.4; IF04-11)

"From the banking perspective, the Gol has not been fully responsible, unlike Singapore. The worst is that SME development would be on a political party's agenda. Moreover, too many Gol agents control and manage SMEs." (IF05-11)

"I admit that the Gol's policy does not fit with the current needs of the SMEs. Funds from the Gol for the SMEs' enlargement are not appropriately placed with those requiring funds for their expansion. Most SMEs first need the knowledge about agility, dynamic flexibility, and sustainability, which is experiential knowledge." (IF07-8, IF10-3.2 \& 10-1; IF18-12.2; IF11-13)

The authors infer that the end goals for these Indonesian SMEs are sustainability, agility and dynamic flexibility. These SMEs probably gain three capabilities through their sociodynamic factors and disruptive innovation. Meanwhile, the SMEs' achievements would probably not be supported by the Gol due to different knowledge levels. The authors argue that the $\mathrm{Gol}$, as a regulator and an aggregator, facilitates 
these SMEs. Most Indonesian SMEs need the Gol to facilitate integrated social media's ICT for disseminating knowledge (Ainin, Parveen, Moghavvemi, Jaafar, \& Shuib, 2015; Morgan, Colebourne, \& Thomas, 2006; Scuotto, Del Giudice, \& Obi Omeihe, 2017). This dissemination is helpful for these SMEs because it could enhance their knowledge efficiently and effectively. Of course, this enhancement is through the sociodynamics that the SMEs utilise for making disruptive innovation.

With another approach, the Gol enhance the SMEs' knowledge using an industrial parenting scheme. This parenting system is relevant to the sociodynamic factors because knowledge transfers occur from the listed firms in the capital market to SMEs. This study argues that whether the SMEs' sociodynamic capabilities within these firms' parenting systems are achieved, the supply chain's connectivity is held automatically among the big firms and these SMEs (Bordonaba-Juste \& Cambra-Fierro, 2009; Tan, Smith, \& Saad, 2006). In other words, the Gol could facilitate collaboration among them. Finally, intensive partnerships, supported by the Gol, would improve these SMEs' social capital (Diehr \& Wilhelm, 2017; Figueiredo \& Piana, 2018; Roberts, Lawson, \& Nicholls, 2006). Then, the Gol could direct these SMEs to induce helpful foresight information for gaining future economic benefits. Therefore, its policy could increase the SMEs' sociodynamics simultaneously. Moreover, it would be better when the social media's ICT supports these SMEs, controlled by the regulators.

\section{Conclusions}

First of all, this study investigates how the Indonesian SMEs' maintain their operating continuance although they have been under chaotic pressure from the COVID-19 pandemic. The authors argue that the SMEs acquired sociodynamic factors and disruptive innovations and applied them in their businesses. Then, this study investigates the SMEs' behaviour regarding these sociodynamic factors and disruptive innovations, their strategic formulation, and the future signifying policies. It proposes that all these SMEs gained sustainability due to the sociodynamic factors used to create disruptive innovations (Mesquita \& Boiger, 2014; Zhang \& Zhu, 2021). Over a short time, these SMEs entered all types of social media's ICT to get experiential knowledge and foresight information (Morgan et al., 2006; Pandit et al., 2018). This preliminary information of the SMEs' search for potential future markets and customer demands. These SMEs also intensively accumulate knowledge, which forms the basis of their disruptive innovation, focusing on product cost reductions and marketing differentiation.

This study analyses the SMEs' operation to complement regulator requirements and banking opinions. The authors find six structuration behaviours conducted by these Indonesian SMEs. First, SMEs improve their entrepreneurial characteristics. They dare to search for integrative information to construct their agility. Moreover, they internalise behavioural intelligence for thinking dynamically, liberating relationships, and adapting flexibility (Dhami, Mandel, Mellers, \& Tetlock, 2015). Second, Indonesian SMEs always expend exceptional knowledge to empower their businesses' readiness. In other words, they undertake a learning process (Bojovic, Genet, \& Sabatier, 2018; Dugundji \& Gulyás, 2012), especially for capturing future uncertainties. Third, the Indonesian SMEs are eager to make intensive partnerships. This study finds these partnerships act as social capital (Diehr \& Wilhelm, 2017; Swoboda et al., 2011). 
Moreover, they relate to all kinds of businesses that enhance their capacities. Finally, they also form relationships with other companies formally and informally.

Fourth, most SMEs utilise social media's ICT to gain information and incredibly forward-looking or foresight orientation. They perceive that information is valuable for improving their internal control systems, business processes, products and services to obtain optimal results. This foresight information is first internalised to create disruptive innovation, focusing on value-added identification (Graham, 2019; Sandström et al., 2014). Fifth, the Indonesian SMEs continuously re-engineer their business models. By doing this, they make new business models to accommodate future probable economic benefits. Moreover, the authors infer that these SMEs continuously pursue potential expansion and diversification. Sixth, the Indonesian SMEs face the misfit of Gol policies. They have achieved a position through their sociodynamic capabilities and disruptive innovations, but the Gol still facilitates and accommodates them with a financial loan approach through the banking system. This mismatch therapy from the Gol makes these SMEs feel pressured to stop gaining valuable knowledge for making disruptive innovations. On the other hand, these SMEs could not increase their sociodynamic capabilities due to the Gol's submarginal policies.

This study concludes that Indonesian SMEs have achieved their knowledge levels in sociodynamics and disruptive innovation. The primary managerial level focuses on valuable knowledge for these SMEs to maintain their business with a degree of agility (Prikladnicki, Lassenius, \& Carver, 2018; Schoonjans et al., 2013), dynamic flexibility (Schoonjans et al., 2013; Sumiyana \& Susilo, 2021) and sustainability (Darcy et al., 2014; Shields \& Shelleman, 2015). Moreover, this study infers that these SMEs conduct learning processes to improve their businesses' capacities gradually. It then highlights that SMEs' learning and knowledge have substance over the other paradigms (Hartarto et al., 2020; Lehner \& Simlinger, 2019), such as financial aid or credit. On the other hand, most Indonesian SMEs continuously forage for forward-looking information that can support their disruptive innovation agenda (Crema \& Nosella, 2014; Pandit et al., 2018). Moreover, these SMEs utilise foresight information to formulate firm strategies. Social networks are a strategy that Indonesian SMEs primarily pursue to be induced in their business activities.

\section{Consequenses For The Goi}

This study considers that the position of Indonesian SMEs is at the point of sufficient knowledge of sociodynamics and disruptive innovation. On the other hand, this study indicates that the Gol's policy still involves programs related to financial credits. Therefore, even though the Gol is concerned with programs, these programs do not fit the needs of the SMEs. The needs gaps have consequences for the Gol, for developing social networks for the SMEs to build an ecosystem, open access to global markets, encourage digital transformation, etc. Therefore, the essence of the Gol's programs must meet the needs of the SMEs, which in turn will have an impact on increasing the capacity of the SMEs (Bhasin \& Venkataramany, 2010; Doh \& Kim, 2014). On the other hand, SMEs must be open 
and active in accessing government programs according to their needs to accelerate their business level improvements.

Gol policies should increase the capacity of the SMEs' agility, dynamic flexibility, and sustainability. These policies should be paradigms of the sociodynamic factors and disruptive innovations for these SMEs. In other words, this study encourages a series of policies that specifically aim to develop the sociodynamic and disruptive innovation capabilities among all Indonesian SMEs (Karami \& Tang, 2019; Zhang \& Zhu, 2021). Gol's practical policy encourages the formation of active SMEs' social networks. Moreover, the Gol should work with parties to assist the SME community (Juergensen, Guimón, \& Narula, 2020; Vega, Brown, \& Chiasson, 2012). Furthermore, the primary Gol policy bundles all the SMEs' social networks for nationwide operational capacity. The function of these bundled social networks is to simultaneously leverage the learning process for all SMEs. In other words, the Gol should have the role of providing business intelligence for all these Indonesian SMEs, including for their products, marketing, market areas, etc. Furthermore, the Gol should encourage close links between national research programs and business needs. These research results are essential for SMEs because they always get the latest updated valuable knowledge.

\section{Limitation}

The authors recognised that this study contains weaknesses in accomplishing this research. First, this study's sampling method selects SMEs that still operate and improve their businesses. In other words, all the respondents are SMEs that have managed to enlarge their businesses. It means that this study contains survival bias in its sampling method. However, this study maintains these selected samples with answers from respondents homogeneously. The second bias is that this study conducted in-depth interviews using the zoom-link. Consequently, the authors could not transfer knowledge perfectly, and vice versa. Imperfect knowledge transformations probably influence the comprehensivity of the interviews' contents because the interviewer could not capture the respondents' gimmicks to achieve a more extraordinary validation.

\section{Abbreviations}

SMEs: Small and Medium-sized Enterprises

DAE: Deloitte Access Economics

ICT: Information and Communication Technology

DCS: Digital Controlling System

Gol: Government of Indonesia

\section{Declarations}




\section{Acknowledgements}

The authors acknowledge Gadjah Mada University's Research Directorate that finances this research.

\section{Authors' contributions}

All authors have contributed to this study equally, from proposal development to manuscript writing stages. All authors read and approved the final manuscript.

\section{Funding}

This research has received funding from Gadjah Mada University's Research Directorate, 2021.

\section{Availability of data and materials}

The datasets generated during and analysed during the current study are available from the corresponding author on reasonable request.

\section{Competing interests}

The authors declare that they have no competing interests.

\section{Author Details}

Jenri MP Panjaitan is an associate professor in the Faculty of Social \& Political Science, Bina Nusantara University, Indonesia. Muhadjir Darwin is a professor in the Faculty of Social \& Political Science, University of Gadjah Mada, Indonesia. Sumiyana Sumiyana is a professor in the Faculty of Economics \& Business, University of Gadjah Mada, Indonesia. Wivaqqusaniyyah Wiva is a lecturer in the Leadership \& Policy Innovation, University of Gadjah Mada, Indonesia. Servatia M. Setyowati is a lecturer in the Faculty of Economics \& Business, Duta Wacana Christian University, Indonesia.

\section{References}

1. Ainin, S., Parveen, F., Moghavvemi, S., Jaafar, N. I., \& Shuib, N. L. M. (2015). Factors influencing the use of social media by SMEs and its performance outcomes. Industrial Management \& Data Systems. doi:10.1108/IMDS-07-2014-0205

2. Ali, Z., Gongbing, B., \& Mehreen, A. (2018). Does supply chain finance improve SMEs performance? The moderating role of trade digitisation. Business Process Management Journal. doi:10.1108/BPMJ-05-2018-0133 
3. Alraja, M. N., Hussein, M. A., \& Ahmed, H. M. S. (2021). What affects digitalisation process in developing economies? An evidence from SMEs sector in Oman. Bulletin of Electrical Engineering and Informatics, 10(1), 441-448. doi:https://doi.org/10.11591/eei.v10i1.2033

4. Aschauer, E., Moro, A., \& Massaro, M. (2015). The auditor as a change agent for SMEs: the role of confidence, trust and identification. Review of Managerial Science, 9(2), 339-360. doi:10.1007/s11846-014-0162-4

5. Assink, M. (2006). Inhibitors of disruptive innovation capability: a conceptual model. European journal of innovation management. doi:10.1108/14601060610663587

6. Ates, A., Garengo, P., Cocca, P., \& Bititci, U. (2013). The development of SME managerial practice for effective performance management. Journal of small business and enterprise development. doi:https://doi.org/10.1108/14626001311298402

7. Bekhet, A. K., \& Zauszniewski, J. A. (2012). Methodological triangulation: An approach to understanding data. Nurse researcher. doi:10.7748/nr2012.11.20.2.40.c9442

8. Bhasin, B. B., \& Venkataramany, S. (2010). Globalisation of entrepreneurship: Policy considerations for SME development in Indonesia. International Business \& Economics Research Journal (IBER), 9(4), doi:https://doi.org/10.19030/iber.v9i4.557

9. Blagoveshchenskaya, E. A., Dashkina, A. I., Lazovskaya, T. V., Ryabukhina, V. V., \& Tarkhov, D. A. (2016). Neural network methods for construction of sociodynamics models hierarchy. International Symposium on Neural Networks, 513-520. doi:https://doi.org/10.1007/978-3-319-40663-3_59

10. Bojovic, N., Genet, C., \& Sabatier, V. (2018). Learning, signalling, and convincing: The role of experimentation in the business modelling process. Long Range Planning, 51(1), 141-157. doi:https://doi.org/10.1016/j.Irp.2017.09.001

11. Bordonaba-Juste, V., \& Cambra-Fierro, J. J. (2009). Managing supply chain in the context of SMEs: a collaborative and customised partnership with the suppliers as the key for success. Supply Chain Management: An International Journal. DOI: 10.1108/13598540910980305

12. Bouwman, H., Nikou, S., \& de Reuver, M. (2019). Digitalisation, business models, and SMEs: How do business model innovation practices improve performance of digitalising SMEs?

Telecommunications Policy, 43(9), 101828. doi:https://doi.org/10.1016/j.telpol.2019.101828

13. Candas, S., Siala, K., \& Hamacher, T. (2019). Sociodynamic modelling of small-scale PV adoption and insights on future expansion without feed-in tariffs. Energy Policy, 125, 521-536. doi:https://doi.org/10.1016/j.enpol.2018.10.029Agility

14. Chan, C. M., Teoh, S. Y., Yeow, A., \& Pan, G. (2019). Agility in responding to disruptive digital innovation: Case study of an SME. Information Systems Journal, 29(2), 436-455. doi:https://ink.library.smu.edu.sg/soa_research/1831

15. Chen, J., Zhu, Z., \& Zhang, Y. (2017). A study of factors influencing disruptive innovation in Chinese SMEs. Asian Journal of Technology Innovation, 25(1), 140-157.

doi:10.1080/19761597.2017.1302552 
16. Christensen, G., \& Miguel, E. (2018). Transparency, reproducibility, and the credibility of economics research. Journal of Economic Literature, 56(3), 920-980. doi:10.3386/w22989

17. CIPS (2021). Siaran Pers | Digitalisasi, Solusi UMKM Bertahan Selama Pandemi. Retrieved from Retrieved September 4, 2021 https://id.cips-indonesia.org/post/siaran-pers-digitalisasi-solusi-umkmbertahan-selama-pandemi

18. Čiutienè, R., \& Thattakath, E. W. (2014). Influence of dynamic capabilities in creating disruptive innovation. Economics and Business, 26, 15-21. doi:10.7250/eb.2014.015

19. Cohen, L., Manion, L., \& Morrison, K. (2002). Research methods in education (5th ed.). Routledge

20. Corsaro, D., Cantù, C., \& Tunisini, A. (2012). Actors' heterogeneity in innovation networks. Industrial Marketing Management, 41(5), 780-789. doi:https://doi.org/10.1016/j.indmarman.2012.06.005

21. Crema, M., \& Nosella, A. (2014). Intangible assets management and evaluation: Evidence from SMEs. Engineering Management Journal, 26(1), 8-20.

doi:https://doi.org/10.1080/10429247.2014.11432000

22. Creswell, J. W., \& Creswell, J. D. (2017). Research design: Qualitative, quantitative, and mixed methods approaches Sage publications

23. Darcy, C., Hill, J., McCabe, T., \& McGovern, P. (2014). A consideration of organisational sustainability in the SME context: A resource-based view and composite model. European Journal of Training and Development. doi:https://doi.org/10.1108/EJTD-10-2013-0108

24. Denzin, N. K. (1970). A theoretical introduction to sociological methods. Chicago, IL: Aldlne

25. Dhami, M. K., Mandel, D. R., Mellers, B. A., \& Tetlock, P. E. (2015). Improving intelligence analysis with decision science. Perspectives on Psychological Science, 10(6), 753-757. doi:https://doi.org/10.1177\%2F1745691615598511

26. Diehr, G., \& Wilhelm, S. (2017). Knowledge marketing: How can strategic customers be utilised for knowledge marketing in knowledge-intensive SMEs? Knowledge Management Research \& Practice, 15(1), 12-22. doi:https://doi.org/10.1057/s41275-016-0039-1

27. Doh, S., \& Kim, B. (2014). Government support for SME innovations in the regional industries: The case of government financial support program in South Korea. Research Policy, 43(9), 1557-1569. doi:https://doi.org/10.1016/j.respol.2014.05.001

28. Dugundji, E. R., \& Gulyás, L. (2012). Sociodynamic discrete choice on networks in space: role of utility parameters and connectivity in emergent outcomes. Procedia Computer Science, 10, 827-832. doi:10.1016/j.procs.2012.06.107

29. Figueiredo, P. N., \& Piana, J. (2018). Innovative capability building and learning linkages in knowledge-intensive service SMEs in Brazil's mining industry. Resources Policy, 58, 21-33. doi:https://doi.org/10.1016/j.resourpol.2017.10.012

30. Flick, U. (2018). Triangulation in data collection. The SAGE handbook of qualitative data collection

31. Gabbioneta, C., Greenwood, R., Mazzola, P., \& Minoja, M. (2013). The influence of the institutional context on corporate illegality. Accounting, Organisations and Society, 38(6-7), 484-504. 
doi:https://doi.org/10.1016/j.aos.2012.09.002

32. Gentles, S. J., Charles, C., Ploeg, J., \& McKibbon, K. A. (2015). Sampling in qualitative research: Insights from an overview of the methods literature. The qualitative report, 20(11), 1772-1789

33. Gibbs, G. R. (2018). Analysing qualitative data (6 vol.). Sage

34. Gobble, M. M. (2016). Defining disruptive innovation. Research-Technology Management, 59(4), 6671. doi:https://doi.org/10.1080/08956308.2016.1185347

35. Graham, A. (2019). Choice and Social Stability: The Morphogenesis of a Sociodynamic Constant. doi:10.31235/osf.io/hyjd8

36. Guion, L. A., Diehl, D. C., \& McDonald, D. (2011). Triangulation: Establishing the validity of qualitative studies. Edis, 2011(8), 3-3

37. Gujarati, D. N., Porter, D. C., \& Gunasekar, S. (2012). Basic econometrics: Tata McGraw-Hill Education

38. Guttentag, D. (2015). Airbnb: disruptive innovation and the rise of an informal tourism accommodation sector. Current Issues in Tourism, 18(12), 1192-1217. doi:10.1080/13683500.2013.827159

39. Hambrick, D. C., \& Lovelace, J. B. (2018). The role of executive symbolism in advancing new strategic themes in organisations: A social influence perspective. Academy of Management Review, 43(1), 110-131. doi:https://doi.org/10.5465/amr.2015.0190

40. Hartarto, A., Panjaitan, J. M., \& Sumiyana, S. (2020). A new method to empower organisational readiness for change in Indonesian SMEs. Entrepreneurship and Sustainability Issues, 8(2), 230. doi:http://doi.org/10.9770/jesi.2020.8.2(14)

41. Heale, R., \& Forbes, D. (2013). Understanding triangulation in research. Evidence-based nursing, 16(4), 98-98. doi:10.1136/eb-2013-101494

42. Jeansson, J., \& Bredmar, K. (2019). Digital transformation of SMEs: Capturing complexity. Paper presented at the 32nd Bled eConference: Humanizing Technology for a Sustainable Society, Bled, Slovenia, June 16-19, 2019

43. Juergensen, J., Guimón, J., \& Narula, R. (2020). European SMEs amidst the COVID-19 crisis: assessing impact and policy responses. Journal of Industrial and Business Economics, 47(3), 499510. doi:https://doi.org/10.1007/s40812-020-00169-4

44. Kala'lembang, A. (2021). Digitalisation in increasing SMEs productivity in the post-COVID-19 pandemic period. Management and Entrepreneurship: Trends of Development, 2(16), 101-110. doi:https://doi.org/10.26661/2522-1566/2021-1/16-08

45. Karami, M., \& Tang, J. (2019). Entrepreneurial orientation and SME international performance: The mediating role of networking capability and experiential learning. International Small Business Journal, 37(2), 105-124. doi:https://doi.org/10.1177/0266242618807275

46. Kornberger, M., Justesen, L., \& Mouritsen, J. (2011). "When you make manager, we put a big mountain in front of you": An ethnography of managers in a Big 4 accounting firm. Accounting, Organisations and Society, 36(8), 514-533. doi:https://doi.org/10.1016/j.aos.2011.07.007 
47. Latifi, M. A., Nikou, S., \& Bouwman, H. (2021). Business model innovation and firm performance: Exploring causal mechanisms in SMEs. Technovation, 107, 102274. doi:https://doi.org/10.1016/j.technovation.2021.102274

48. Lehner, O. M., \& Simlinger, R. (2019). When function meets emotion, change can happen: Societal value propositions and disruptive potential in fintech. The International Journal of Entrepreneurship and Innovation, 20(4), 277-288. doi:https://doi.org/10.1177/1465750319857974

49. Manish, G., \& Sutter, D. (2016). Mastery versus profit as motivation for the entrepreneur: How crony policies shape business. Journal of Entrepreneurship and Public Policy. doi:10.1108/JEPP-10-20150032

50. Markides, C. (2006). Disruptive innovation: In need of better theory. Journal of product innovation management, 23(1), 19-25

51. Mesquita, B., \& Boiger, M. (2014). Emotions in context: A sociodynamics model of emotions. Emotion Review, 6(4), 298-302. doi:https://doi.org/10.1177\%2F1754073914534480

52. Morgan, A., Colebourne, D., \& Thomas, B. (2006). The development of ICT advisors for SME businesses: An innovative approach. Technovation, 26(8), 980-987.

doi:https://doi.org/10.1016/j.technovation.2005.09.001

53. Murphey, T., Falout, J., Fukuda, T., \& Fukada, Y. (2014). Socio-dynamic motivating through idealising classmates. System, 45, 242-253. doi:https://doi.org/10.1016/j.system.2014.06.004

54. Nagy, D., Schuessler, J., \& Dubinsky, A. (2016). Defining and identifying disruptive innovations. Industrial Marketing Management, 57, 119-126.

doi:https://doi.org/10.1016/j.indmarman.2015.11.017

55. Pandit, D., Joshi, M. P., Sahay, A., \& Gupta, R. K. (2018). Disruptive innovation and dynamic capabilities in emerging economies: Evidence from the Indian automotive sector. Technological Forecasting and Social Change, 129, 323-329. doi:https://doi.org/10.1016/j.techfore.2017.09.035

56. Pantano, E., Pizzi, G., Scarpi, D., \& Dennis, C. (2020). Competing during a pandemic? Retailers' ups and downs during the COVID-19 outbreak. Journal of Business Research, 116, 209-213. doi:https://doi.org/10.1016/j.jbusres.2020.05.036

57. Pearson, D. W., Albert, P., Besombes, B., Boudarel, M. R., Marcon, E., \& Mnemoi, G. (2002). Modelling enterprise networks: A master equation approach. European Journal of Operational Research, 138(3), 663-670

58. Prikladnicki, R., Lassenius, C., \& Carver, J. C. (2018). Trends in agileupdated: Perspectives from the practitioners. IEEE Software, 35(1), 109-111. doi:10.1109/MS.2017.4541042

59. Priyono, A., Moin, A., \& Putri, V. N. A. O. (2020). Identifying digital transformation paths in the business model of SMEs during the COVID-19 pandemic. Journal of Open Innovation: Technology, Market, and Complexity, 6(4), 104. doi:https://doi.org/10.3390/joitmc6040104

60. Renz, S. M., Carrington, J. M., \& Badger, T. A. (2018). Two strategies for qualitative content analysis: An intra-method approach to triangulation. Qualitative health research, 28(5), 824-831. doi:https://doi.org/10.1177/1049732317753586 
61. Roberts, S., Lawson, R., \& Nicholls, J. (2006). Generating regional-scale improvements in SME corporate responsibility performance: Lessons from responsibility Northwest. Journal of Business Ethics, 67(3), 275-286. doi:10.1007/s10551-006-9184-4

62. Robson, P. J., \& Bennett, R. J. (2000). SME growth: The relationship with business advice and external collaboration. Small business economics, 15(3), 193-208

63. Sandström, C., Berglund, H., \& Magnusson, M. (2014). Symmetric assumptions in the theory of disruptive innovation: Theoretical and managerial implications. Creativity and Innovation Management, 23(4), 472-483. doi:https://doi.org/10.1111/caim.12092

64. Schlosser, F. (2015). Identifying and differentiating key employees from owners and other employees in SMEs. Journal of Small Business Management, 53(1), 37-53. doi:https://doi.org/10.1111/jsbm.12066

65. Schmidt, G. M., \& Druehl, C. T. (2008). When is a disruptive innovation disruptive? Journal of product innovation management, 25(4), 347-369

66. Schoonjans, B., Van Cauwenberge, P., \& Vander Bauwhede, H. (2013). Formal business networking and SME growth. Small business economics, 41(1), 169-181. doi:10.1007/s11187-011-9408-6

67. Scott, C., \& Medaugh, M. (2017). Axial coding. The international encyclopedia of communication research methods, 10, 9781118901731. doi:10.1002/9781118901731.iecrm0012

68. Scuotto, V., Del Giudice, M., \& Obi Omeihe, K. (2017). SMEs and mass collaborative knowledge management: toward understanding the role of social media networks. Information Systems Management, 34(3), 280-290. doi:http://dx.doi.org/10.1080/10580530.2017.1330006

69. Shields, J., \& Shelleman, J. M. (2015). Integrating sustainability into SME strategy. Journal of Small Business Strategy, 25(2), 59-78

70. Sumiyana, S. (2020). Different characteristics of the aggregate of accounting earnings between developed and developing countries: Evidence for predicting future GDP. Journal of international studies, 13(1), doi:10.14254/2071-8330.2020/13-1/4

71. Sumiyana, S., Atmini, S., \& Sugiri, S. (2019). Predictive power of aggregate corporate earnings and their components for future GDP growths: An international comparison. Economics \& Sociology, 12(1), 125-367. doi:10.14254/2071-789X.2019/12-1/7

72. Sumiyana, S., \& Susilo, G. F. (2021). Beneficial Explanation for SME's E-Commerce Adoption: The Sequential Stages of Organizational, Industrial and National Readiness. Economics \& Sociology, 14(2), 252-273. doi:10.14254/2071789X.2021/14-2/14

73. Svensrud, E., \& Åsvoll, H. (2012). Innovation in large corporations: A development of the rudimentary theory of effectuation. Academy of Strategic Management Journal, 11(1), 59

74. Swoboda, B., Meierer, M., Foscht, T., \& Morschett, D. (2011). International SME alliances: the impact of alliance building and configurational fit on success. Long Range Planning, 44(4), 271-288. doi:https://doi.org/10.1016/j.lrp.2011.04.002

75. Taiminen, H. M., \& Karjaluoto, H. (2015). The usage of digital marketing channels in SMEs. Journal of small business and enterprise development. doi:https://doi.org/10.1108/JSBED-05-2013-0073 
76. Tan, E. N., Smith, G., \& Saad, M. (2006). Managing the global supply chain: an SME perspective. Production planning \& control, 17(3), 238-246. doi:https://doi.org/10.1080/09537280500285417

77. Tyler, B., Lahneman, B., Beukel, K., Cerrato, D., Minciullo, M., Spielmann, N., \& Discua Cruz, A. (2020). SME managers' perceptions of competitive pressure and the adoption of environmental practices in fragmented industries: A multi-country study in the wine industry. Organization \& Environment, 33(3), 437-463. doi:10.1177/1086026618803720

78. Vega, A., Brown, D., \& Chiasson, M. (2012). Open innovation and SMEs: Exploring policy and the scope for improvements in university-based public programmes through a multidisciplinary lens. International Journal of Entrepreneurial Behavior \& Research.

doi:https://doi.org/10.1108/13552551211239492

79. Walia, R. (2015). A saga of qualitative research. Social Crimonol, 5(2), 124. doi:10.4172/23754435.1000124

80. Walley, P. (2013). Stakeholder management: the sociodynamics approach. International Journal of Managing Projects in Business. doi:https://doi.org/10.1108/IJMPB-10-2011-0066

81. Wan, F., Williamson, P. J., \& Yin, E. (2015). Antecedents and implications of disruptive innovation: Evidence from China. Technovation, 39, 94-104.

doi:https://doi.org/10.1016/j.technovation.2014.05.012

82. Williams, M., \& Moser, T. (2019). The art of coding and thematic exploration in qualitative research. International Management Review, 15(1), 45-55

83. Zhang, F., \& Zhu, L. (2021). Social media strategic capability, organisational unlearning, and disruptive innovation of SMEs: The moderating roles of TMT heterogeneity and environmental dynamism. Journal of Business Research, 133, 183-193.

doi:https://doi.org/10.1016/j.jbusres.2021.04.071 